\title{
Situating STS and Thinking Ahead
}

\author{
ADELE E. CLARKE \\ UNIVERSITY OF CALIFORNIA, SAN FRANCISCO
}

\begin{abstract}
This essay sketches some of the broader sociopolitical and academic conditions of possibility at the time of the founding of the SKAT Section of the American sociological Association, noting the diversity of concerned groups and the affordances of epistemological diversity. I situate my own development as an early STS scholar, and discuss the growing salience of (post)colonial STS and concerns regarding current STS training and publishing.
\end{abstract}

\section{Keywords}

political history of STS; feminist STS; theory-methods packages; epistemological diversity; STS training; (post)colonial STS

\section{Introduction}

To mark the $25^{\text {i }}$ anniversary of the Science, Knowledge and Technology Section (SKAT) of the American Sociological Association, its newsletter offered an excellent article on its founding. ${ }^{2}$ But the origins of STS and SKAT in the context of their broader sociopolitical and academic conditions of possibility transnationally are not widely known. In this essay's first section I sketch some of these conditions. One theme concerns the diversity of groups concerned with sciences, technologies and medicines (hereafter STEMS), and another the affordances of pluralist approaches to knowledge--epistemological diversity (Anderson 2006, 8). I then briefly situate my own development as an early STS scholar whose work crosses disciplinary and other divides. In the last section I discuss some concerns regarding future STS training and publishing, and the growing salience of (post)colonial STS. While I use our usual shorth "STS," I mean feminist / or non-feminist science, technology and medicine studies.

\footnotetext{
· Adele Clarke, Email: Adele.Clarke@ucsf.edu SSee Sweeney (2015).

Copyright (C) 2016 (Adele Clarke). Licensed under the Creative Commons Attribution Non-commercial No Derivatives (by-nc-nd). Available at estsjournal.org.
} 


\section{Situating SKAT and STS}

Broader activist and academic political situations at the time of SKAT's emergence contributed to its being founded as a section called SKAT rather than the sociology of science. SKAT is the North American instantiation of transnational, transdisciplinary allied but distinctive social movement-like groupings centered on the study of sciences, technologies, and medicines, including feminist approaches. They emerged from 1960s-inspired politics and had earlier progressive roots. That is, if there was a "long civil rights movement" as Alondra Nelson (2013) has eloquently demonstrated, there was also a "long (feminist) science, technology and medicine studies movement."

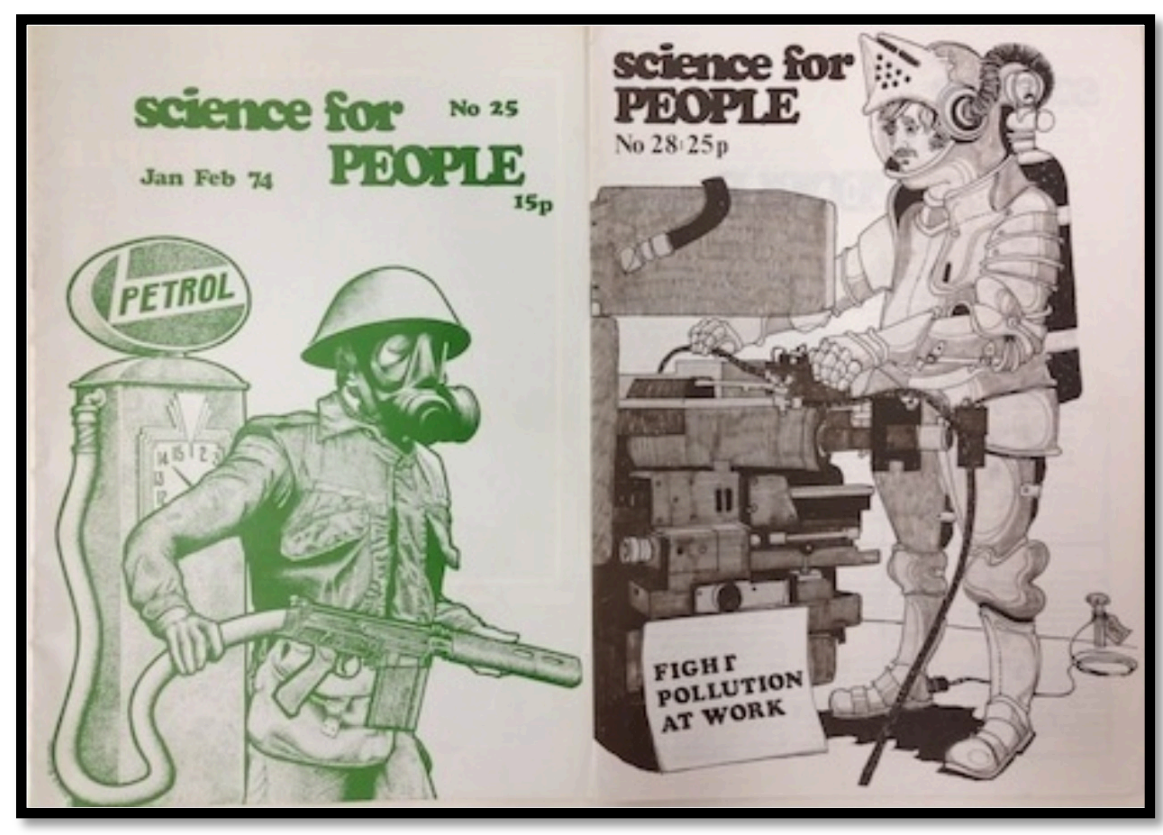

Figure 1: Cover of Science for People, magazine of the British Society for Social Responsibility in Science (Bell 2013).

After WWII, the Cold War was built on STEMS through superb state support under capitalist, communist, and other regimes. STEMS criticism (parallel to art criticism) emerged quickly and powerfully, especially in Britain (e.g., Werskey 1978). The British Society for Social Responsibility in Science (BSSRS), founded in 1969, was central to the "radical science movement," and members included J.D. Bernal and Francis Crick (Bell 2013).

See http:/ / www.bssrs.org/clients/ resources (last accessed 5/30/16). 


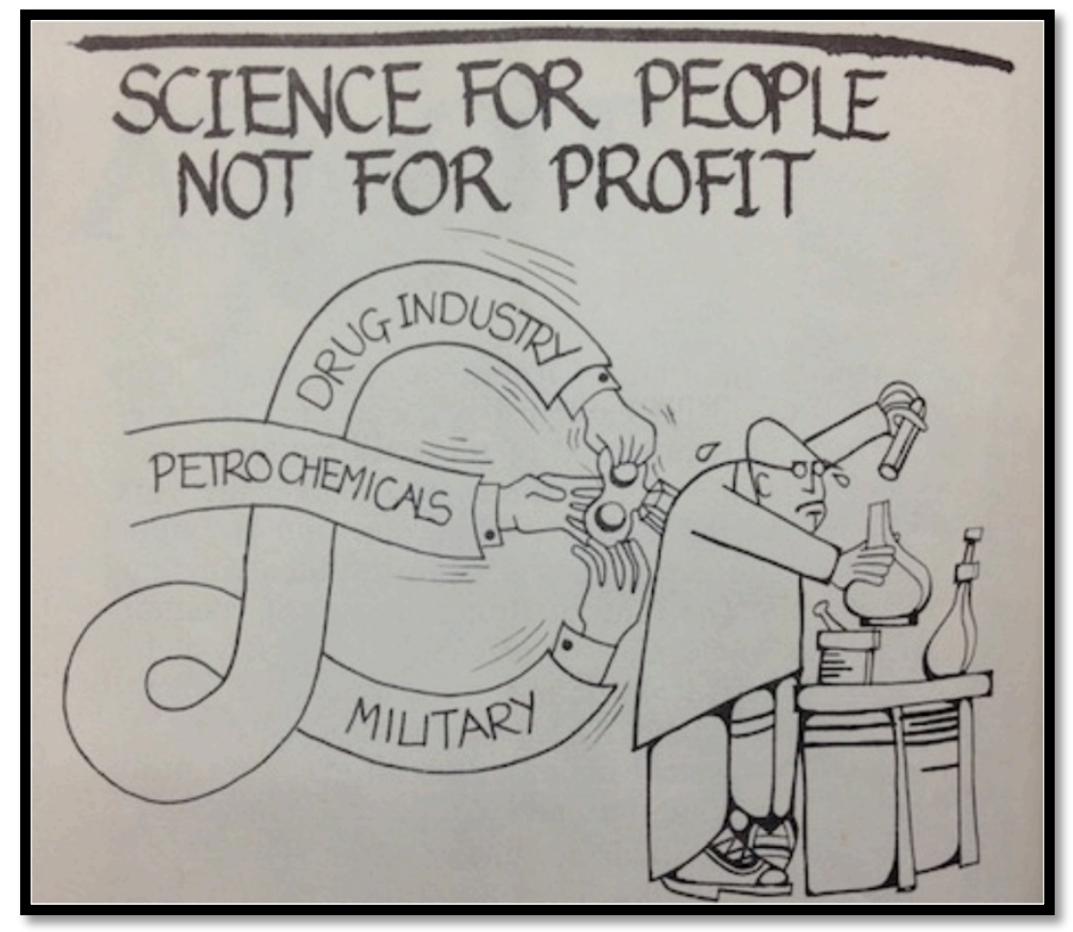

Figure 2: “Funding a Scientist," cartoon from Science for People, Issue 43 (Bell 2013).

The U.K. tradition of scientists as policy wonks and public intellectuals was overtly recognized at the University of Edinburgh, which established a Science Studies Unit in 1966. It taught a required course for all science and engineering students toward better fulfilling their roles far beyond the laboratory. David Edge ([1998] 1999), Unit co-founder and founding editor of Social Studies of Science, later noted that the course first quite radically:

presented...the "ecology" of the scientific community...what specialties scientists pursued, where (...in what institutions in what countries), who pays for their service. This demonstrated vividly the imbalance between the size of Rich World and Third World science (and its foci), and the extent to which scientists are financed by military and "big business" interests. Second, we presented a kind of "map" of the "political roles" which scientists play--within industry and governmental institutions; as "in-house advisers"... in "freelance" or "outsider" groups (such as...Greenpeace and the Union of Concerned Scientists).

\footnotetext{
. For the 50" anniversary volume, see Mazerani and Schyfter (in preparation).
} 
British scientists were seen as needing some STS to do their policy work!

Meanwhile, in North American academia, disciplinary organizations studying STEMS emerged early including the History of Science Society (1924), the American Association for the History of Medicine (1925), the Philosophy of Science Society (1933) the Society for the History of Technology (1958), the Medical Sociology Section of the ASA (1959), and the Society for Medical Anthropology of the American Anthropological Association (1967). These disciplinary sites were often and sometimes remain inhospitable to the hybrid analytics and multidisciplinary approaches common in STS.

Post-WWII American sociology, significantly including the sociology of science (Zuckerman 1979), was dominated by functionalism. However, outsider groups perceived ASA meetings and journals as "closed shops." Two such groups institutionalized themselves to address their exclusion. One was an amalgam of progressives who bed together as the Society for the Study of Social Problems (SSSP) in 1951, committed to what we now term social justice. ${ }^{5}$ The second group was symbolic interactionists of the Chicago School who institutionalized as the Society for

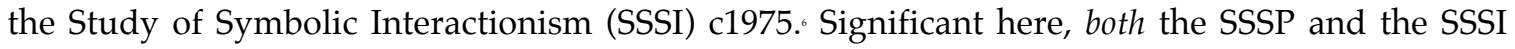
welcomed early STS work, itself often both critical and constructionist.

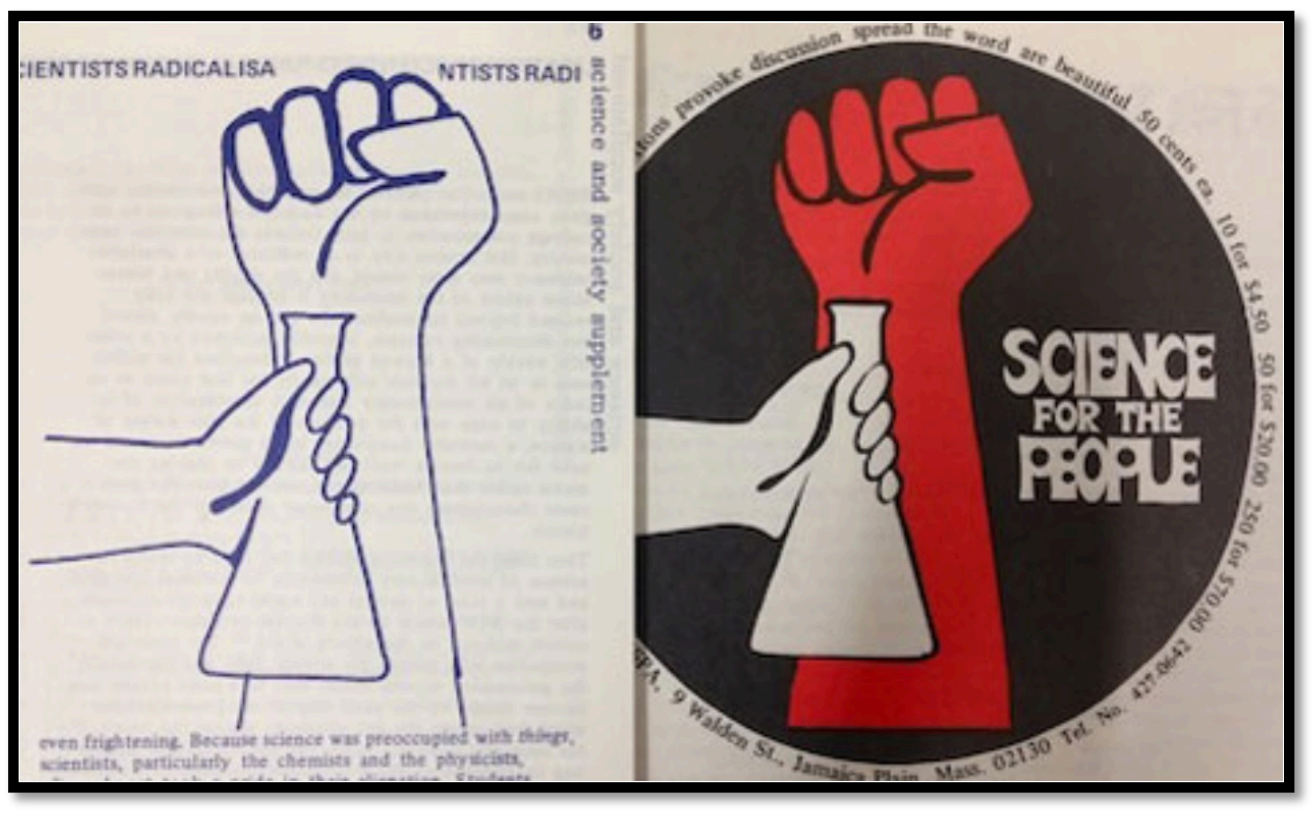

Figure 3: Anti-oppression salute next to chemical flask, as used in UK and US radical science magazines in the 1970s (Bell 2013).

\footnotetext{
"Marxists could not organize an ASA section using his name until c1975, dwelling largely in the SSSP until then. On the history of the SSSP see http://www.sssp1.org/index.cfm/m/453/locationSectionId/0/Who_We_Are (last accessed $6 / 24 / 16)$.

- On the history of the SSSI, see the 1997 Special Issue of Symbolic Interaction 20(2).
} 


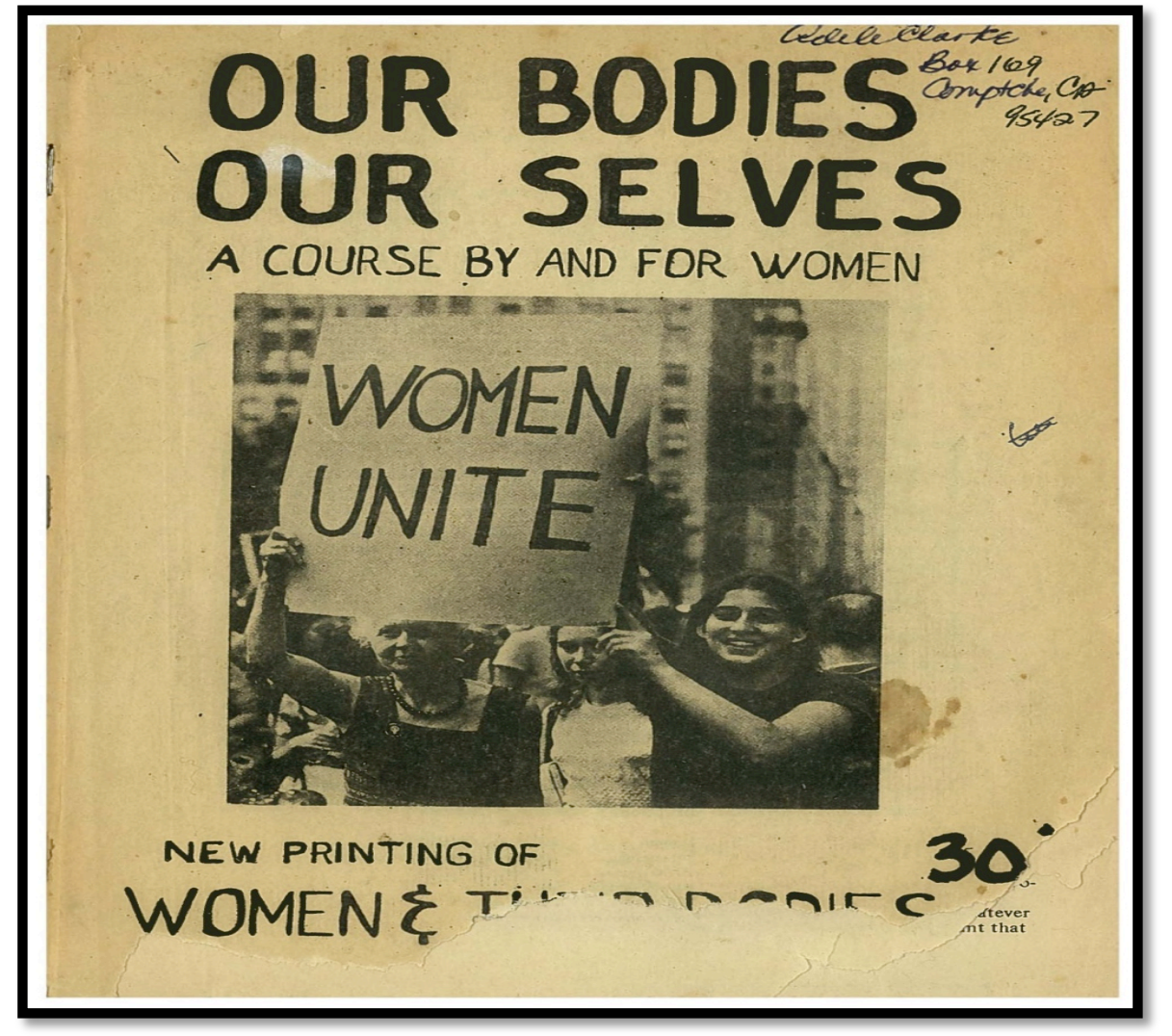

Figure 4: Cover of the First Edition of Our Bodies, Our Selves (Boston Feminist Women's Health Collective 1979).

More pluralist and encompassing STS organizing efforts included the transdisciplinary and transnational Society for Social Studies of Science (4S), established in 1975, and the European Association for the Study of Science and Technology (EASST), founded in 1981. Transnationally, in academic STS - as in feminist academia in the 1970s and 1980s (Fee 1983)--there were lively liberal, socialist, and (neo)Marxist traditions. In the US too, an array of critical movements and incipient institutional efforts began to focus on STEMS and STS. The Bulletin of the Atomic Scientists began in 1945 around nuclear weapons and disarmament. Other groups ranged from anti-war activism to "Science for the People" founded c1970 as both long-standing aspiration and formal organization (e.g., Greeley and Tafler 1980). The US Food and Drug Administration's Frances Kelsey valiantly fought against thalidomide during the 1960s, giving momentum to

? Donald MacKenzie's (1982) "Technology as Capitalist Restructuring" in the Edinburgh interest theory tradition was one (neo)Marxist example. Others included Zilsel (1942) on "The Sociological Roots of Science" and Ravetz's (1971) Scientific Knowledge and its Social Problems. See also e.g., Barnes (1977), MacKenzie (1978) and Werskey (2007). Zilsel's paper was reprinted with commentary in 2000 in Social Studies of Science 30 (6): 925-949. 
various women's health movements such as Our Bodies, Ourselves that were especially critical of medicalization (e.g., Ruzek 1978). ${ }^{\text {. }}$

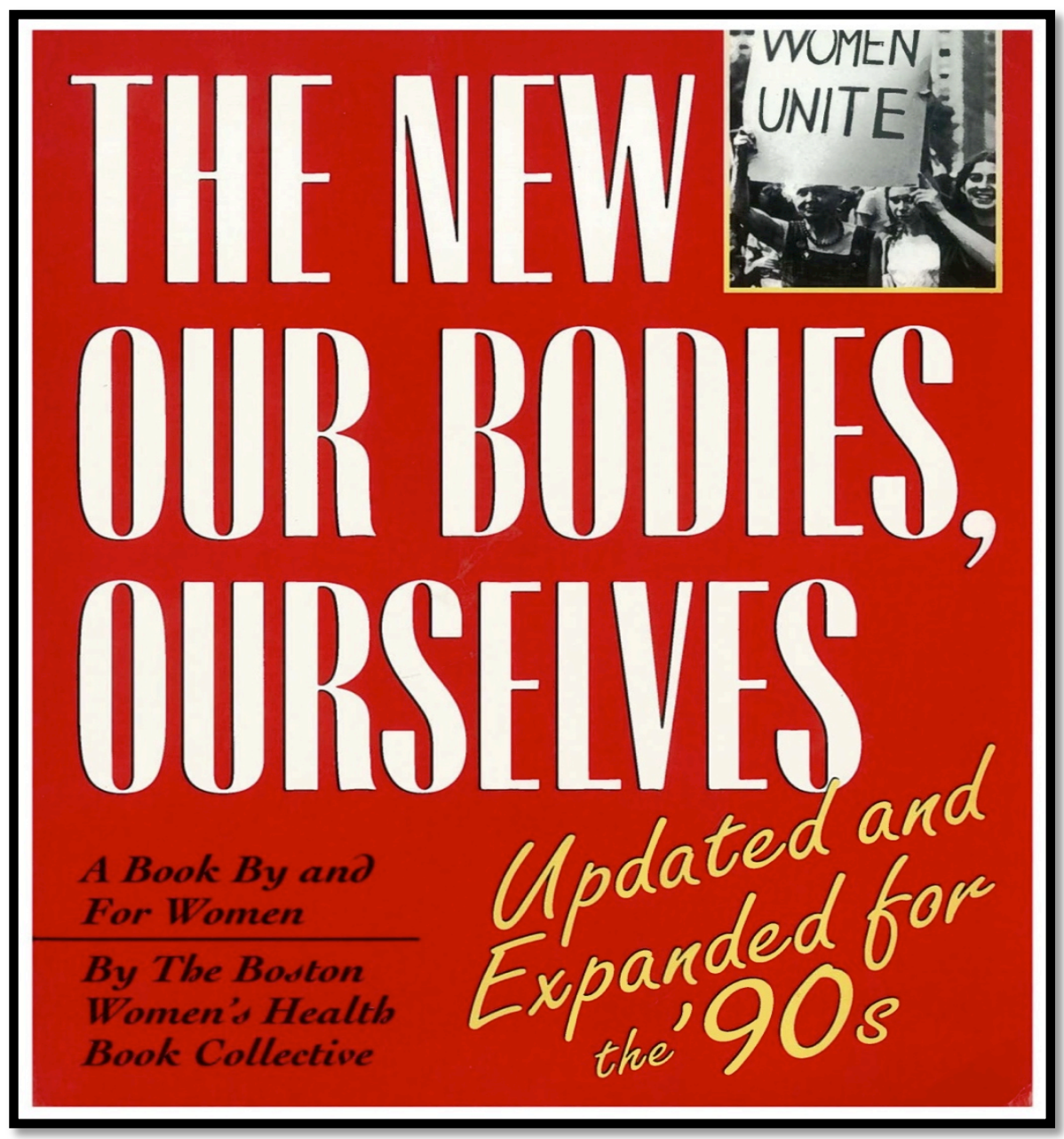

Figure 5: Cover of Our Bodies, Ourselves (Boston Feminist Women's Health Collective 1992).

Rachel Carson's Silent Spring first appeared in The New Yorker in 1962, and Carolyn Merchant's The Death of Nature: Women, Ecology, and the Scientific Revolution in 1980. John and Barbara Ehrenreich published The American Health Empire: Power Profits and Politics for the group

\footnotetext{
she full text of the original stapled version is available

http:// www.ourbodiesourselves.org/cms/assets/uploads/2014/04/Women--Their-Bodies-1970.pdf (last accessed

5/30/16). On its impacts, see http://www.ourbodiesourselves.org/history/impact--influence/ (last accessed 5/30/16). Monica Casper and I contributed on cervical dysplasia and Pap smears to several editions.
} 
Health/PAC in 1970. E. Richard Brown's Rockefeller Medicine Men: Medicine and Capitalism in America appeared in 1979.

US scientists also became involved in activist organizations in tandem with British colleagues. Some were transnational, such as Computer Professionals for Social Responsibility (CPSR), which from 1983 to 2013 sought to provide input on policy and public debate. Others took on projects on sexism and racism in academic science, including R. C. Lewontin, Stephen Jay Gould, Ruth Hubbard and Ruth Bleier.

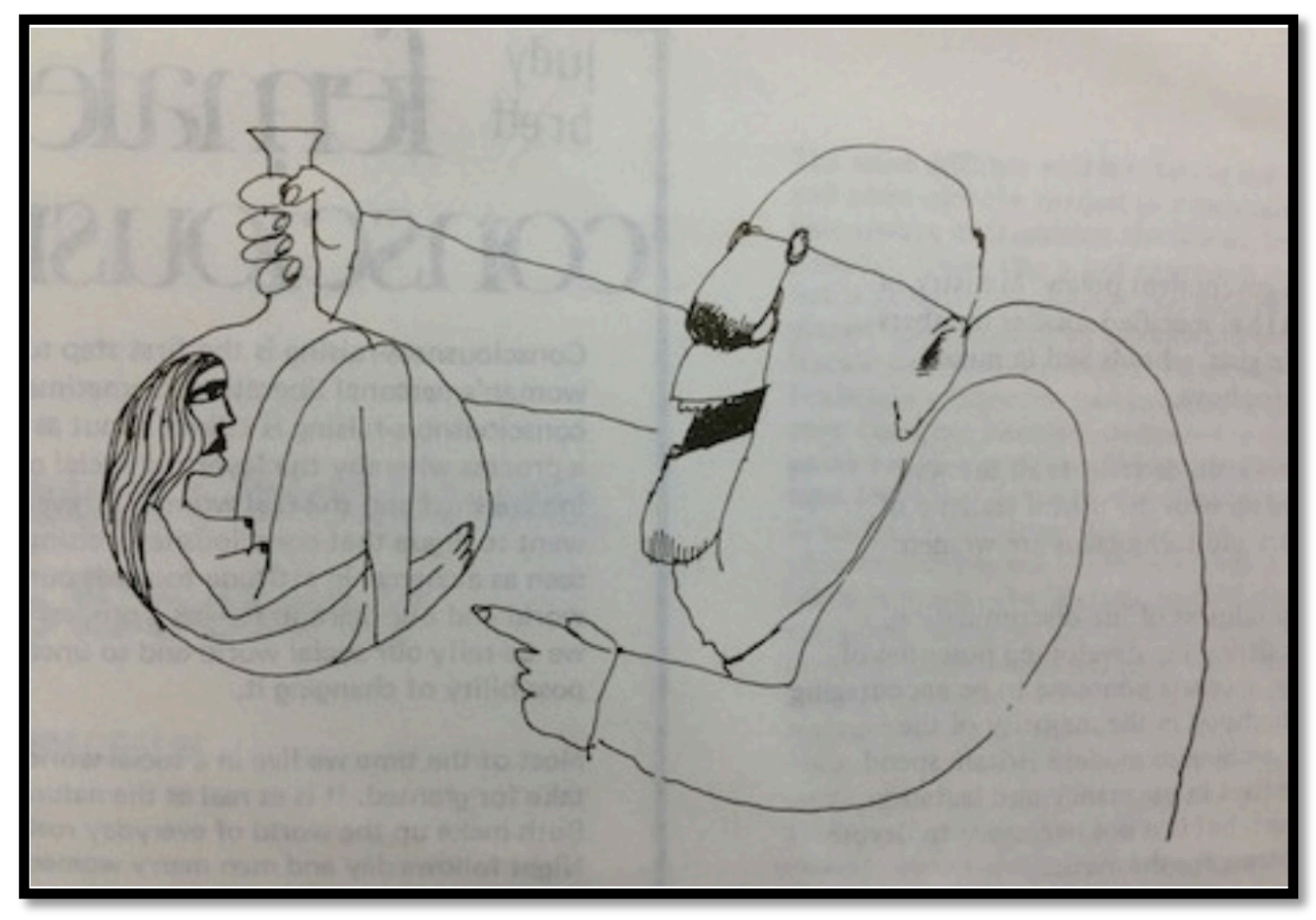

Figure 6: Cartoon Showing the BSSRS's Concern over Sexism in Science (Bell 2013).

These and many others hoped for a joining of Science and Liberation-the title of a book published in 1980 (Arditti, Brennan and Cavrak 1980)—and were committed public intellectuals. There was much overlap among progressive communities, and shared concerns among graduate students from the 1960s onwards that our education and future scholarship should engage such commitments more explicitly towards building what we fervently hoped would be a new world order.

However, conservatives soon joined progressives in STEMS criticism, albeit from other angles. During the neoconservative Reagan administration, the Office of Technology Assessment (OTA) of the US Congress, which operated from 1972-1995, was terminated. The OTA had 
employed sociologists of science, including SKAT founder Daryl Chubin, and produced reports for Congress on acid rain, healthcare, global climate change, and polygraphs. In today's antiscience and anti-intellectual zeitgeist in the US, its closure is unsurprising, but it marked a profound change in how US STEM policies were to be formulated.

In Scandinavia, in sharp contrast, progressive social scientists were thinking about STS questions in relation to technology and labor force policies in units often linked to governments. A major goal was moderating the effects of the introduction of computer and information technologies into workplaces. One offshoot was Computer-Supported Cooperative Work: The Journal of Collaborative Computing and Work Practices, founded in 1992. Major transnational centers of feminist STS scholarship also were founded and sustained in Norway, Sweden, and Denmark.

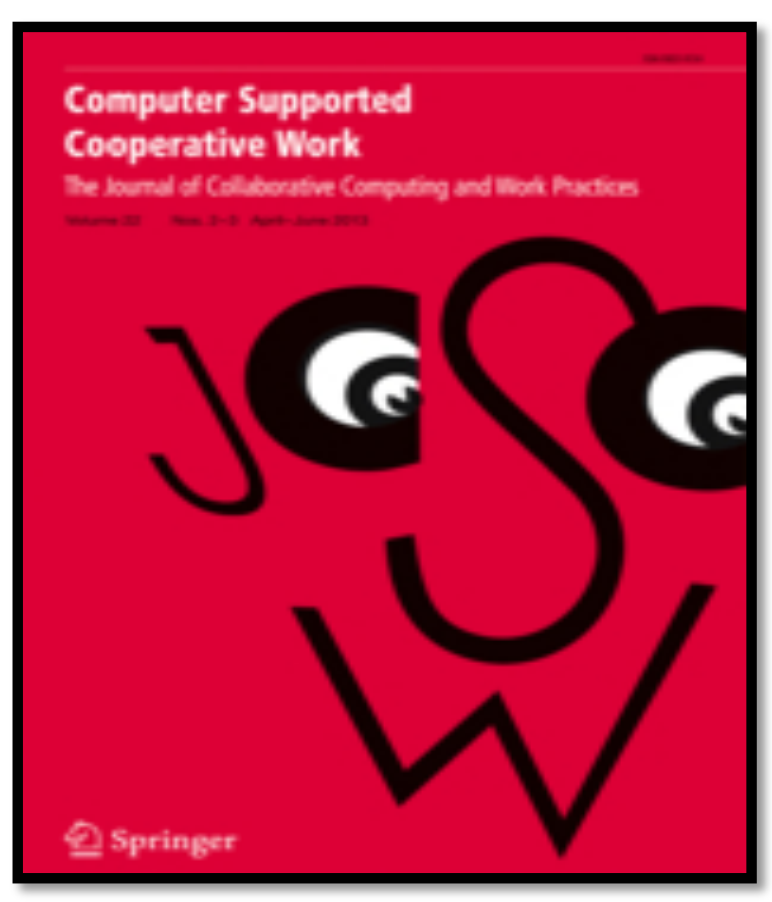

Figure 7: Cover of Computer-Supported Cooperative Work: The Journal of Collaborative Computing and Work Practices (2015).

In France, little work would look like STS to Anglo-American scholars, and there were few institutional sites (Bowker and Latour 1987). But there was Bourdieu's (1975) work on the scientific field, and the Center for the Study of Innovation at the Ecole des Mines.

In India, development of modern technoscience was fundamental to state-making during and after British colonial rule. As its benefits were neither justly nor democratically distributed, it provoked considerable, largely Marxist critique that was vividly captured in Ny's (1988) Science, 
Hegemony and Violence: A Requiem for Modernity. Prakash (1999) later made the (post)colonial argument that Western science was itself transformed through instantiation in (post)colonial settings, thereby constituting "Another Reason" in modern India.

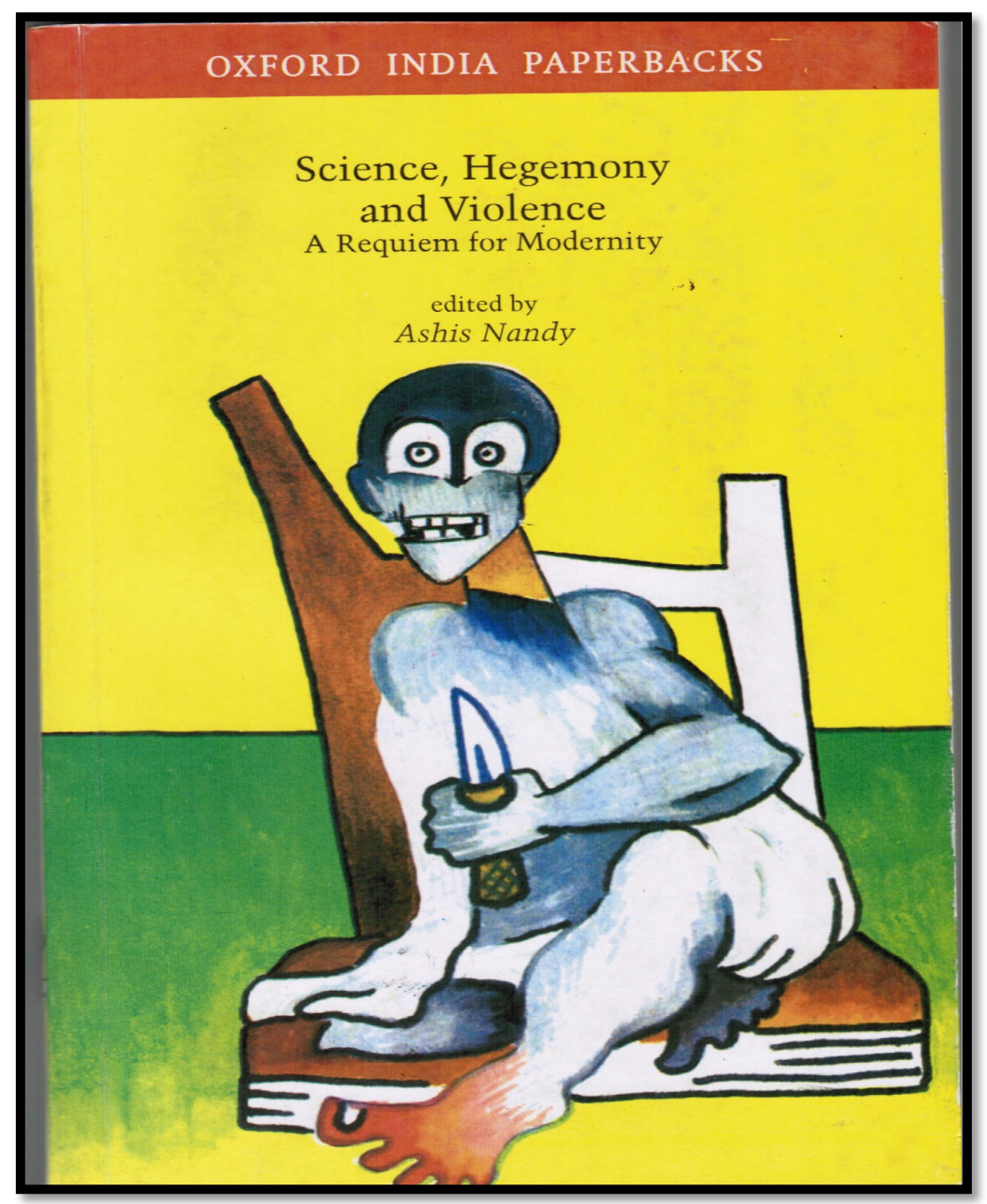

Figure 8: Cover of Ashis Nandy's (1988) Science, Hegemony and Violence: A Requiem for Modernity.

In East Asian countries, history of science and technology were avidly pursued and distinctively inflected nation-based STS groups gradually emerged. This was often through critical science movements such as the South Korean STS group started under Japanese colonial 
dictatorship (e.g., Quet and Noel 2014). As Lin and Law's (2015) recent East Asian Science, Technology and Society journal article asserts, "We Have Never Been Late-comers [to STS]!" Daiwe Fu's (2007) important question, "How Far Can East Asian STS Go?" continues to provoke.

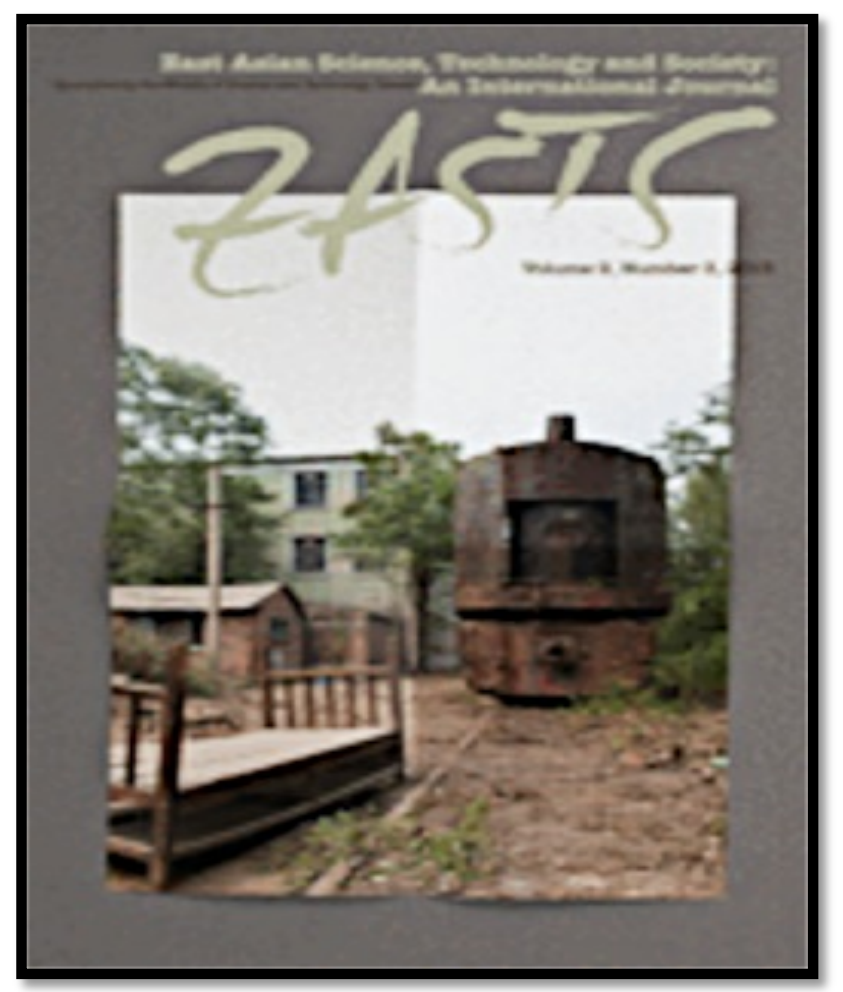

Figure 9: Cover of East Asian Science, Technology and Society 9(3) 2015.

Based in American sociology, SKAT was established in the ASA in c1987. Naming SKAT very much engaged issues of breadth, adding the word "knowledge" explicitly to broaden its scope." Contrary to traditional sociology of science, this signaled SKAT's interest in the content as well as structures of science. And we have grown to fit our name by including such domains as finance and the social sciences as objects of study (e.g., Sweeney 2015). Another radically pluralist STS effort inside American sociology was SKAT-founders' Susan Cozzens' and Tom Gieryn's (1990)

- See Sweeney (2015). One question I have not seen addressed is why a section on the sociology of science was not established in the ASA post-WWII, as there were major centers of such work, largely Mertonian, at Columbia and Harvard (e.g., Zuckerman 1979). 
co-edited Theories of Science in Society featuring functionalists, interactionists, feminists, constructionists, and (neo)Marxists, etc. I was honored to be an invited contributor.

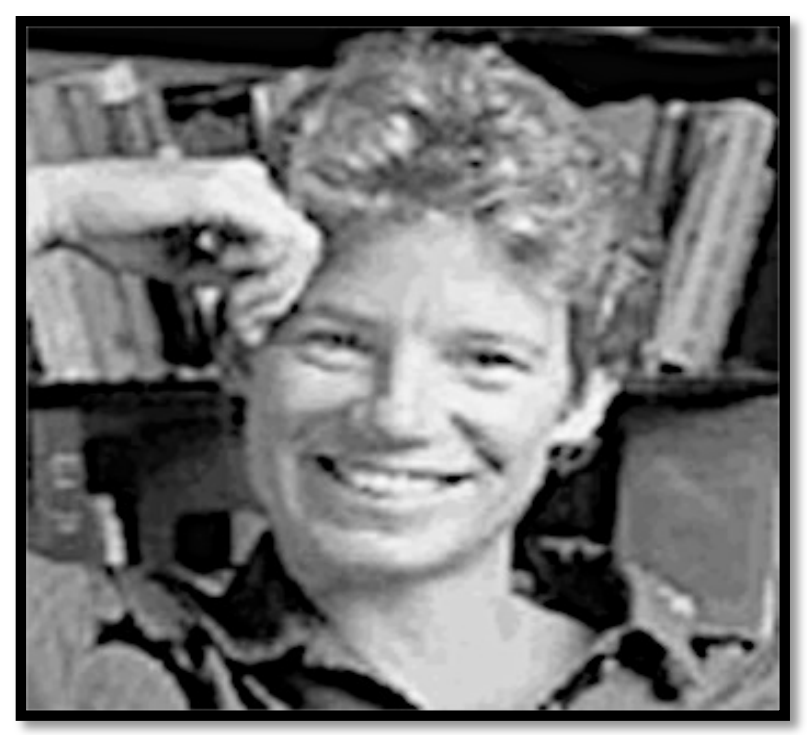

Figure 10: Susan Leigh Star (1954-2010) (Clarke 2010, 581).

To introduce STS to sociology, Leigh Star was invited around 1988 to edit a special issue of Social Problems, journal of the SSSP. ${ }^{\circ}$ A paragraph from her introduction captures the progressive feminist spirit of those times:

Our key questions here are those of general political theory and of feminist and third world liberation movements: Cui bono? Who is doing the dishes? Where is the garbage going? What is the material basis for practice? Who owns the means of knowledge production? The approach begins in a very plain way with respect to science and technology by first taking it "off the pedestal" [Science Off the Pedestal was the title of a book (Chubin and Chu 1989)]" - by treating science as just something that people do together. Some of this means looking at science and technology as the occasion for people to do political work-not necessarily by other means, but fairly directly. Science as a job, science as practice, technology as the means for social movements and political stances, and science itself as a social problem-collectively, these articles take science/technology as the occasion for understanding the political and relational aspects of what we call knowledge (Star [1995, 3] 2016, 15).

10 See Social Problems 35, 1988. This became the core of her edited book (Star 1995).

"Science Off the Pedestal was Chubin and Chu's (1989) introduction to STS. 
These issues still "matter."

The "science wars" of the 1990s, harbingers of neoliberalism, then set STS and feminist STS back in serious ways, repressing our progressive roots and critical edges (e.g., Hilgartner 1997; Hess 2009). Sadly, the "science wars" then fused with the "culture wars" that continue relentlessly in the US and elsewhere. The fact that "science is politics pursued by other means" (Latour 1983, 167-8) is now hypervisible. Happily, we are also seeing a renaissance of the critical edges of STS (e.g., Benjamin this Thematic Collection; Murphy 2012) and many other disciplines and specialties.

\section{(Auto)Biography Meets History}

C. Wright Mills (1959) taught us how biographies and history intermesh, and my own entrée into STS offers an illustration. I came to STS through several routes, many feminist. ${ }^{3}$ First, I began teaching women's studies and women's health in 1973, drawing me into critiques of medicalization and bioscience/biomedicine. My first technology criticism paper, "Me and My Diaphragm: Love at Third Sight," emerged from my "lived experiences" of the Pill and Dalkon Shield as part of the transnational guinea-pig generation of women vis-a-vis contraceptive technologies.

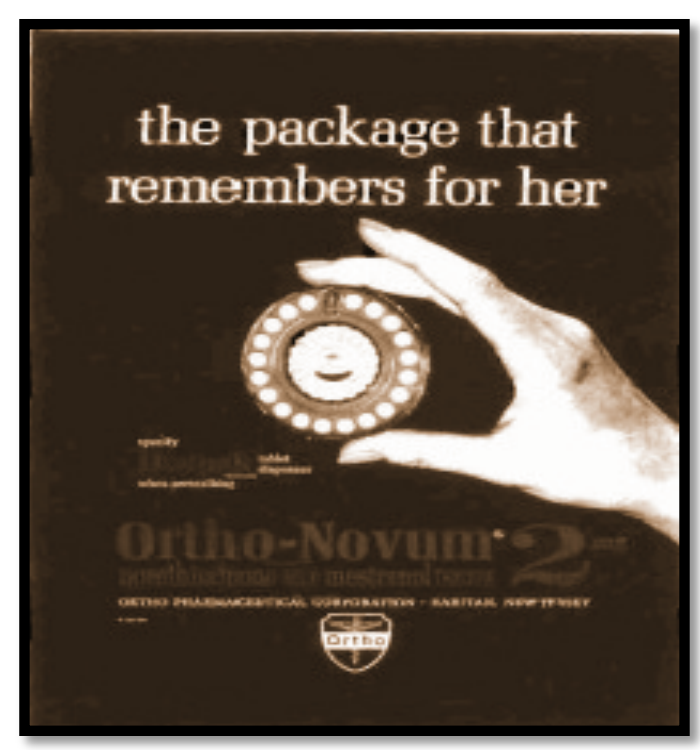

Figure 11: The Birth Control Pill: G.D. Searle \& Co.'s Compak (Gossel 1999:107).

"Sadly, Star died in 2010. A combination festschrift and collection of her major papers has recently been published. See Bowker, Timmermans, Clarke and Balka (2016).

${ }^{3}$ For an autobiography, see Clarke (2012). 
A second source of STS inspiration was the West Coast Socialist Feminist Study Group in the late 1970s, where I met Donna Haraway, Judy Stacey, Gayle Rubin, and others. Third, the women's health movement shaped my feminist and anti-racist STS vision and scholarship. In the Committee to Defend Reproductive Rights, I worked on sterilization abuse, a vicious form of medical racism and sexism, often with eugenic roots.

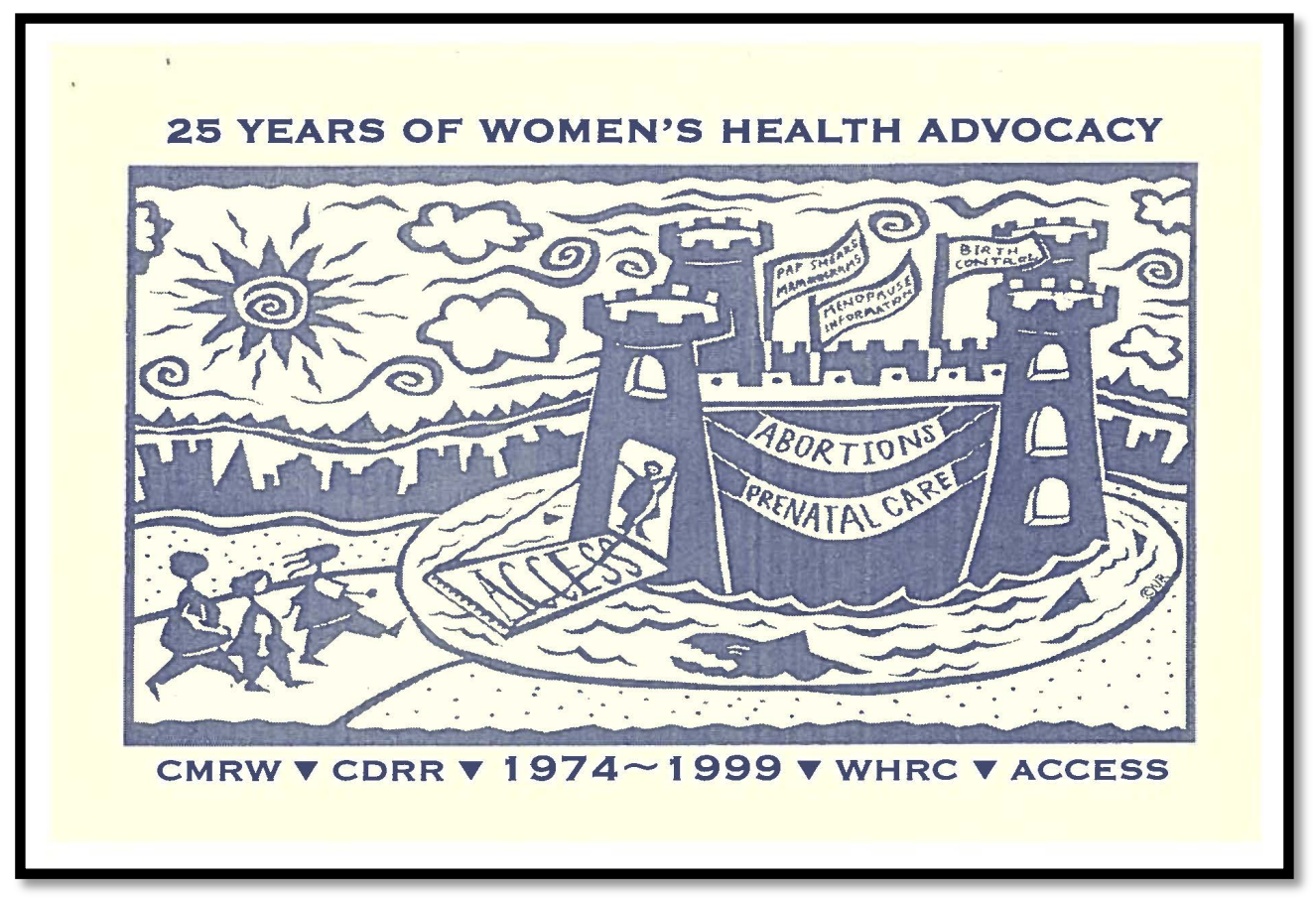

Figure 12: “25 Years of Women's Health Advocacy----CMRW * CDRR * 1974-1999 * WHRC * ACCESS” (Ephemera from the Personal Archive of Adele Clarke).

We published in The Socialist Review, produced by students, faculty, and activists from the San Francisco Bay Area-Steve Epstein later served on the editoriaI collective! Haraway's (1985) "cyborg manifesto" first appeared there, as did my paper on anti-racist reproductive rights organizing (Clarke and Wolfson 1984). These were collected in Women, Class and the Feminist Imagination: A Socialist-Feminist Reader (Hansen and Philipson 1990).

Such initiatives helped generate transdisciplinary and transnational feminist reproduction studies (e.g., Clarke 1983; Clarke 2009), including the excellent Council on 
Anthropology and Reproduction (CAR), founded in 1979, which is transdisciplinary in practice." An early, more STS endeavor was The Cyborg Handbook including my paper (Clarke 1995), illustrated in Figure 13.

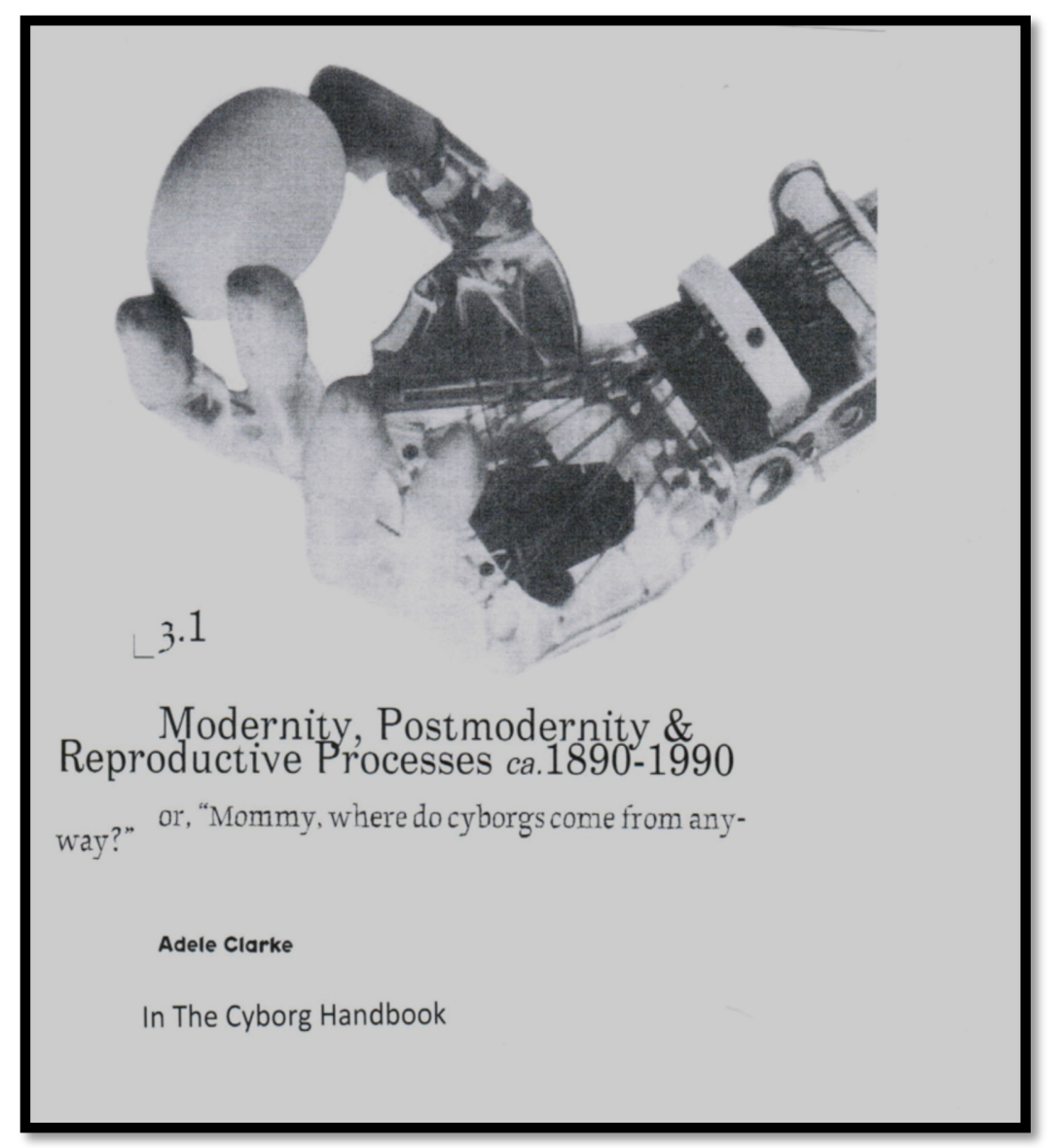

Figure 13: "Modernity, Postmodernity and Human Reproductive Processes c1890-1990, or 'Mommy, Where do Cyborgs Come From Anyway?" (Clarke 1995).

Reproduction studies are increasingly transnational, as is demonstrated by the cover of a 2008 special issue of East Asian Science, Technology and Society: An International Journal that Chialing $\mathrm{Wu}$, Azumi Tsuge and I co-edited.

"It is a Special Interest Group of the Society for Medical Anthropology. See http://www.medanthro.net/car/ (accessed $5 / 30 / 16)$. 


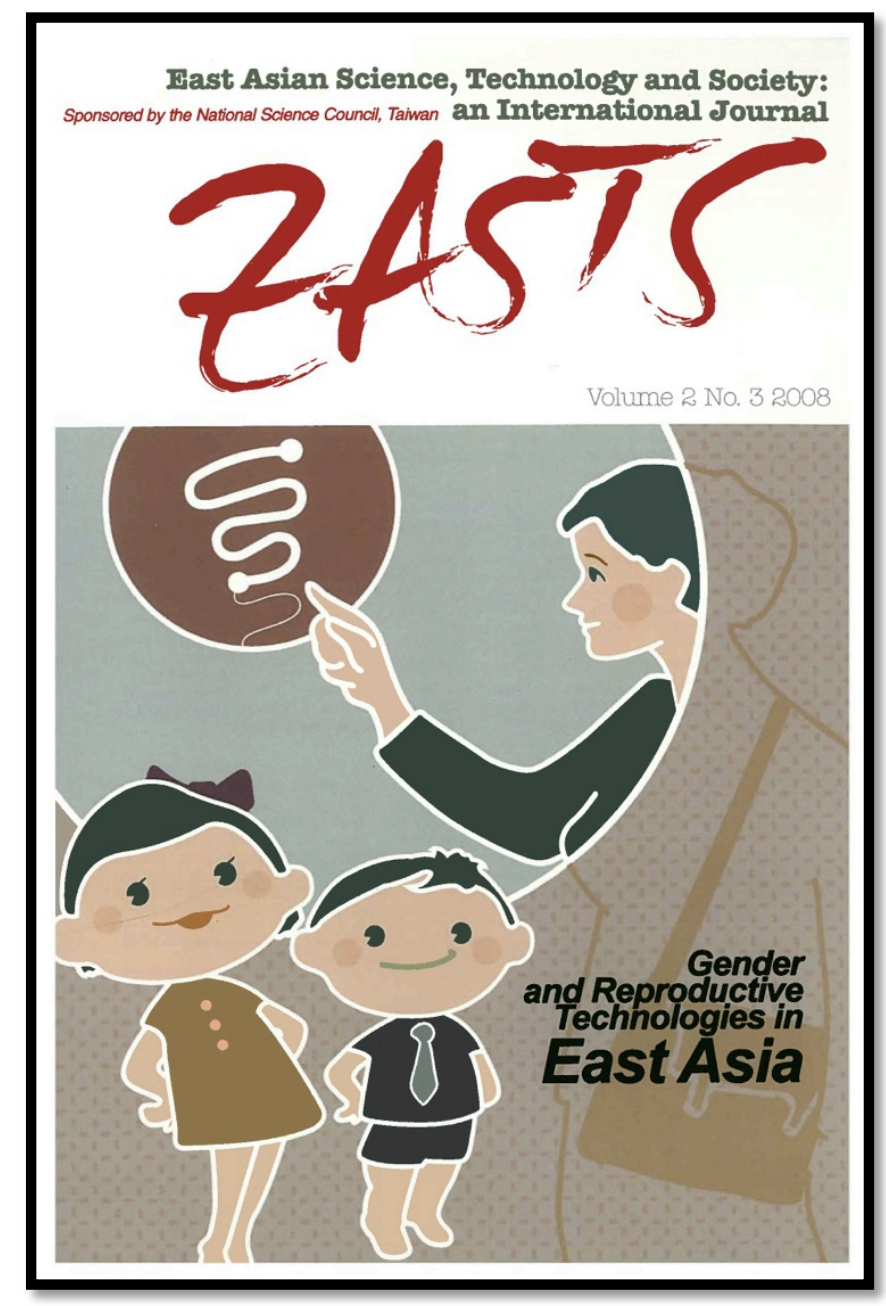

Figure 14: Cover of East Asian Science, Technology and Society (EASTS) Special Issue on Gender and Reproductive Technologies in East Asia, 2008.

An additional influence when I returned to grad school at UCSF in 1980 was another student, Leigh Star. Leigh had earlier participated in Ruth Hubbard's and others' Genes and Gender projects at Harvard (e.g., Star 1979), and became my mentor in STS." My faculty advisor was medical sociologist Anselm Strauss (Figure 15), a strong STS advocate.

${ }^{15}$ I honor her early work on simplification in Clarke (2016). 
Significant here, we were all then identified tribally by theoretical tradition--often quite rigidly. Kuhn's (1962) concept of paradigm quickly took hold, doing valuable clarification work. But disciple-like loyalties often sustained gendered and racialized hierarchies. In co-founding SKAT in 1986, I along with Tom Gieryn, Sue Cozzens, Sal Restivo, Daryl Chubin, Henry Etzkowitz, and others worked against such narrow tribalism. I was a brand new $\mathrm{PhD}$ at 44 , unemployed and terrified as well as honored to join the endeavor.

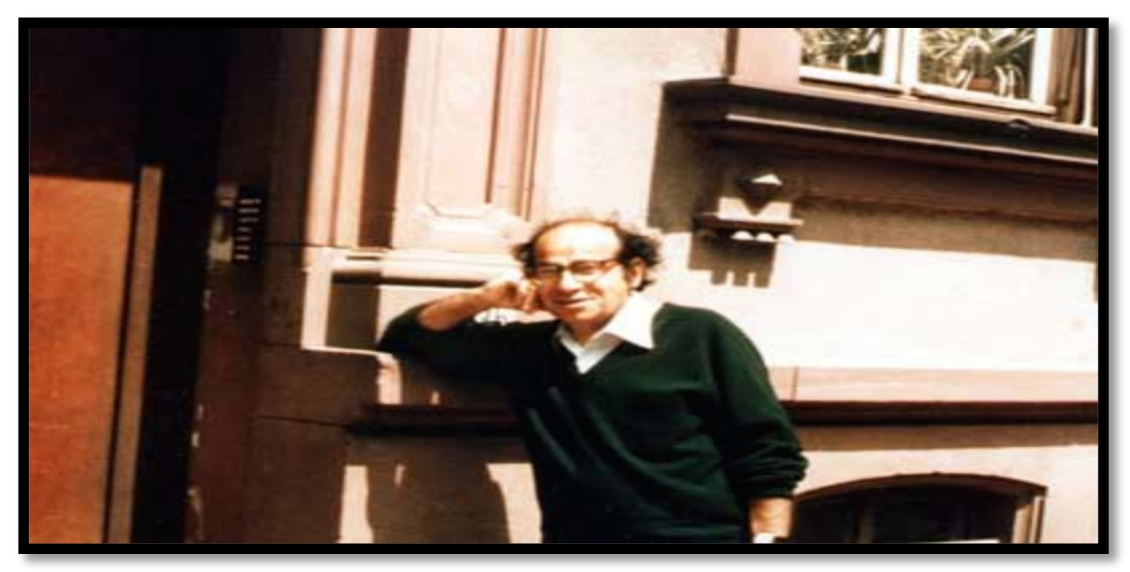

Figure 15: Anselm Strauss (1916-1996) Professor of Sociology, UCSF.

After a postdoc at Stanford studying organizations, I was hired in 1989 by the Doctoral Program in Sociology at UCSF to replace Anselm Strauss, who had retired. There, I developed an STS emphasis deeply entwined with critical medical sociology, feminist, and postcolonial approaches.

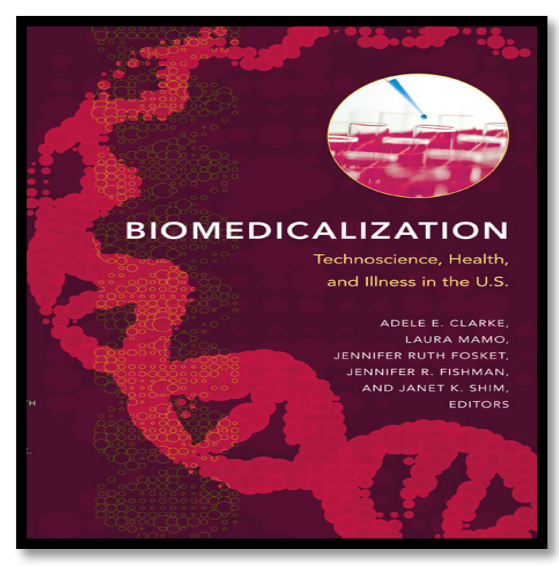

Figure 16: Biomedicalization: Technoscience and Transformations of Health and Illness in the U.S. (2010). 
Monica Casper and I published on the Pap smear technology in both STS and Our Bodies Ourselves. Lisa Jean Moore and I published on female sexual anatomy as what Hess (2009) has since conceptualized as "undone science." Carrie Friese and I compared the use of animal models in reproductive sciences historically. Janet Shim, Laura Mamo, Jennifer Fosket, Jennifer Fishman and I collaborated in the development of biomedicalization and theory. Sara Shostak and Alondra Nelson joined Janet and me in examining it in genetics. I supervised about 25 dissertations with STS emphases and many alumni are active in SKAT and 4S.

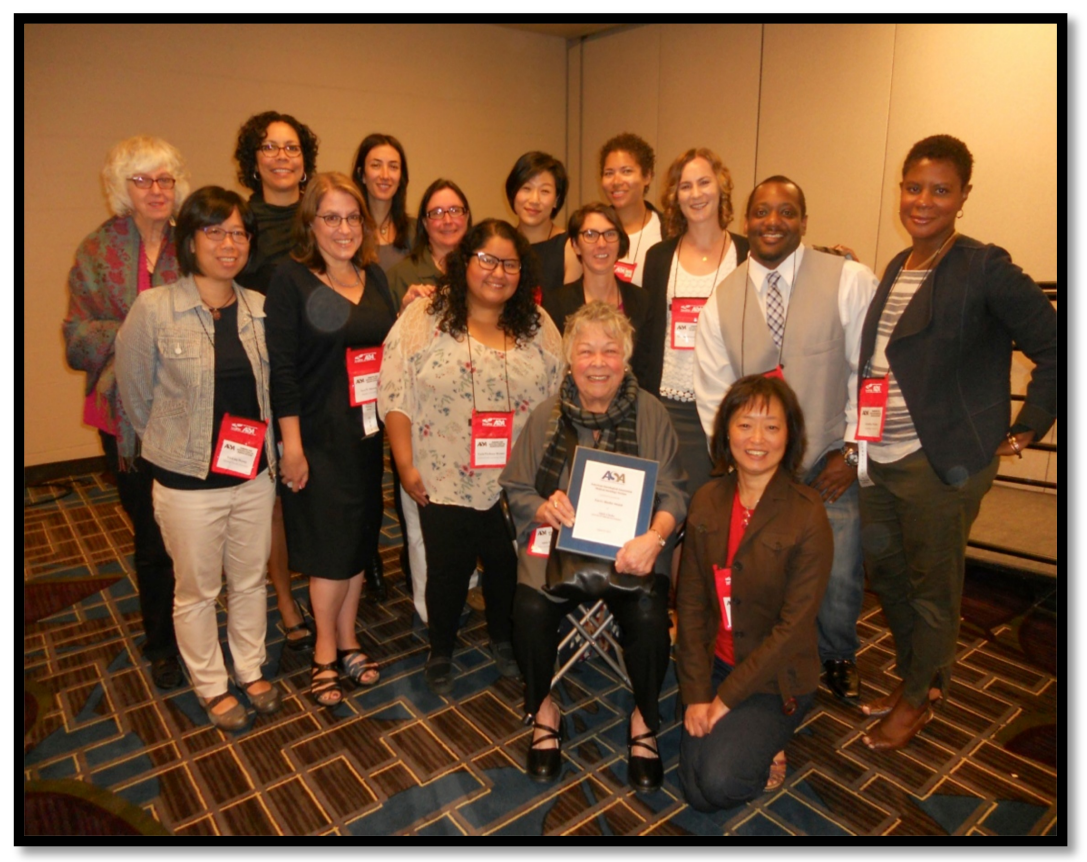

Figure 17: Adele Clarke and Mentees, 2015 (From the Personal Archives of Adele Clarke).

\section{On the Scholarly Future of STS}

I next briefly share several STS frustrations and offer recommendations to address them. Both are negative side-effects of STS's tremendous growth and popularity. Our specialty now draws many people to present at conferences and submit to journals who are inadequately trained in the field. This is painfully obvious to those of us who know the classic questions and works that broadly undergird studies of the production of knowledge. Therefore, I am using this occasion as a platform to call for better training of doctoral students and others interested in STS and for additional training opportunities. People find themselves in STS unexpectedly and dwell in 
institutions lacking such resources. It is requisite for students and newcomers to the specialty to be exposed to both the classical works and to core questions of STS and their manifestations at the contemporary cutting edges of our scholarship. The history of STS matters a lot in STS and beyond.

The time has come for on-line seminars as well as syllabi collections and other resources. Annual conferences might offer a differently themed session each year of "STS 101." For SKAT, this could be a table at the Round Tables that has assigned readings. Other possibilities include the three-day Annual California STS Summer Retreats, ${ }^{16}$ and the University of Wisconsin's 2016 STS Summer School on Disclosing/Enclosing Knowledge in the Life Sciences."

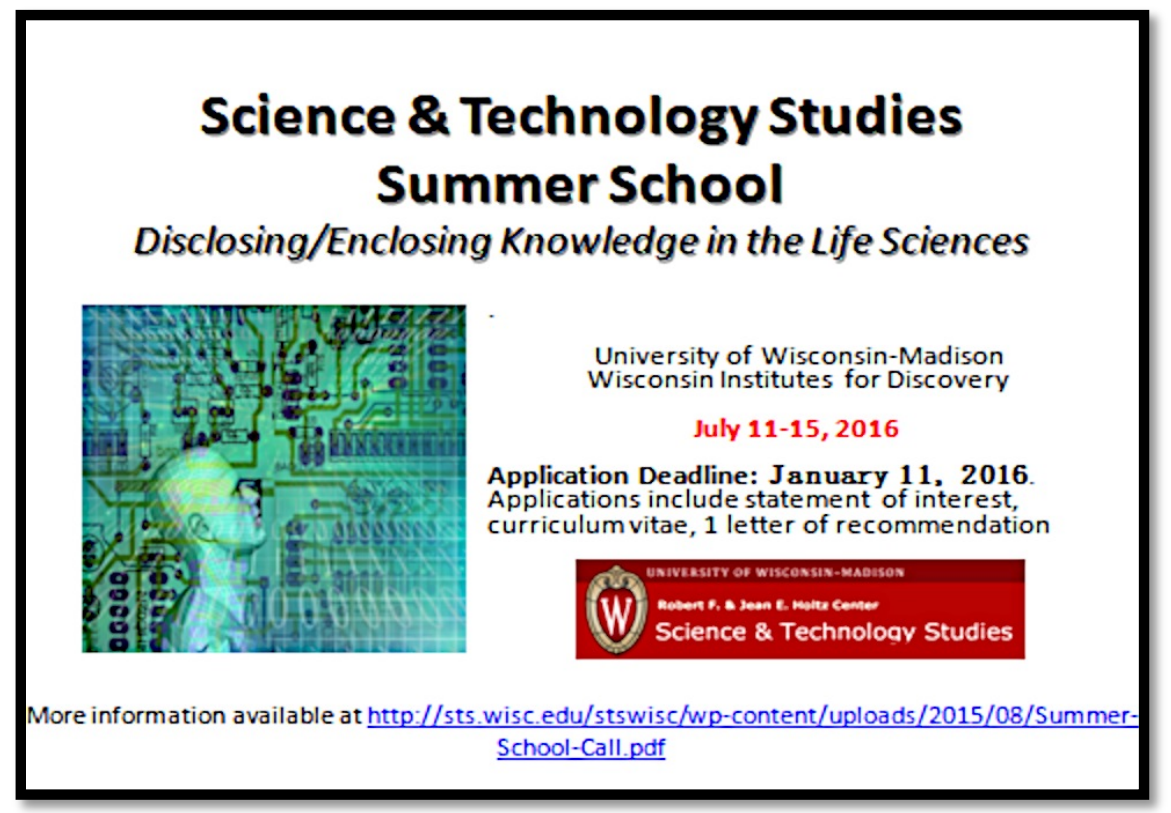

Figure 18: University of Wisconsin STS Summer School, 2016.

There are many other possibilities. If we want the quality of scholarship to improve, we need to enhance people's opportunities to learn-broadly and deeply.

My second concern centers on methods-really "theory-methods packages" (Star 1989). Lately, there has been increasing attention to these in STS." But there are also problems, as Mike

16 Joe Dumit (UC Davis) initiated this in 2006. For further information, email the network at cal.sts.network@gmail.com (accessed 12/22/15).

"See http:/ / sts.wisc.edu/disclosingenclosing .

"E.g., a 2014 special issue of Science, Technology and Human Values 39(2) focused on "The Conceptual and the Empirical in Science and Technology Studies " (Gad and Ribes 2014). And a 2013 special issue of Social Studies of Science 43(3) was 
Lynch $(2012,452)$, former editor of Social Studies of Science, recently noted: "[O]ver the past decade, I have been led to the sad conclusion that the volume of BADANT (Banal and Derivative Actor Network Theory) greatly exceeds the well-researched and broadly informative written work that rides under the ANT banner." I can attest the same is true for grounded theory and situational analysis, having reviewed hundreds of papers for co-edited volumes." Greater attention to "theory-methods packages" is sorely needed in STS training."

Third, there is tremendous need for more explicit critique in reviewing STS papers and books, underscored by my former students' shock at the quality of what they review. Worse, I have read far too many STS books published by university presses that obviously were never sent out to appropriate reviewers. Presses opportunistically publish in our field without generating adequate stables of reviewers, a disservice to authors and STS both.

In terms of future STS directions, I am most excited about intersections among technoscience, gender, race, and (post)coloniality that were relatively invisible in early STS. The issues they pose are expanding dramatically. As Warwick Anderson $(2015,652)$ argues:

Even if explicit recourse to postcolonial theory remains rare in science and technology studies, a postcolonial sensibility has infiltrated its critical scholarship....The imperial gaze sees smooth, inescapable global flows; postcolonial critics instead see messy, uneven politics and diverse, contending agents amid the historical debris.

One key future direction, then, is analyzing these "messy, uneven politics and diverse, contending agents" vis-à-vis all kinds of sciences, technologies, and (bio)medicines." One valuable contribution, especially for teaching and doctoral guidance, would be a volume delineating the historical development of STS in different countries / or regions.

\section{Conclusions}

I end with an excerpt from a candidate statement for SKAT office by Daryl Chubin that reflects the progressive science criticism movements that seeded STS: "I see the fledgling Section of Science, Knowledge, and Technology as an affirmation that a new generation of sociologists recognizes science and technology as problem-creating as well as problem-solving..." ${ }^{2}$ This captures both the underlying politics and the significance of the shift to social studies of science, knowledge, and technology. It has indeed been an honor and a pleasure to be part of STS since 1982 and SKAT since its founding.

titled "A Turn to Ontology in Science and Technology Studies?" (Woolgar and Lezaun 2013), with responses in Social Studies of Science 45(3): 441-467.

"See Clarke and Charmaz (2014) and Clarke, Friese and Washburn (2015).

${ }^{20}$ For review articles, see the various STS handbooks. On social worlds/arenas theory as a "theory-methods package," see Clarke and Star (2007) and Clarke (2010).

"See also e.g., Fu (2007) and Anderson (2012).

"Anderson (2015:652) carefully notes that Latour's (1993) We Have Never Been Modern is "implicitly postcolonial. Thus an analysis that deconstructs imperial binaries such as nature-culture, modern-traditional, global-local builds on a postcolonial, or decolonizing, platform."

Q Quoted in Sweeney (2015:8, emphasis added). 


\section{Acknowledgements}

I thank Warwick Anderson, Geof Bowker, Monica Casper, Jia-shin Chen, Steven Epstein, Daniel Kleinman, Mike Levesque, Sara Shostak, Rachel Washburn and Katie Vann for valuable comments, and Monica, Steve, Daniel Katie for especially close reads.

\section{References}

Anderson, E. 2006. “The Epistemology of Democracy." Episteme: A Journal of Social Epistemology 3(1-2): 8-22.

Anderson, W. 2012. "Asia as Method in Science and Technology Studies." EASTS: East Asian Science, Technology and Society: An International Journal 6 (4): 445-451.

Anderson, W. 2015. "Postcolonial Science Studies." International Encyclopedia of the Social and Behavioral Sciences, ed. J. D. Wright, $2^{\text {nd }}$ ed. Vol. 18: 652-657.

Arditti, R., P. Brennan and S. Cavrak, eds. 1980. Science and Liberation. Boston: South End Press.

Bell, A \. 2013. "Beneath the White Coat: The Radical Science Movement." The Guardian, Thursday 18 July 2013 02.00 EDT. Last modified on Wednesday 21 May 2014. http:/ / www.theguardian.com/science/ political-science/2013/jul/18/ beneath-whitecoat-radical-science-movement (last accessed 12/28/15).

Benjamin, R. 2016. "Catching Our Breath: Critical Race STS and the Carceral Imagination." Engaging Science, Technology, and Society 2: 145-156. DOI:10.17351/ests2016.70

Bowker, G. B. Latour. 1987. "A Booming Discipline Short of Discipline." Social Studies of Science 17(4): 715-748.

Boston Women's Health Course Collective. 1971. Our Bodies, Ourselves. Boston: New England Free Press.

Boston Feminist Women's Health Book Collective. 1992. Our Bodies, Ourselves. New York: Simon and Schuster.

Bourdieu, P. 1975. "The Specificity of the Scientific Field and the Social Conditions of the Progress of Reason." Social Science Information 14 (6): 19-47.

Bowker, G., S. Timmermans, A. E. Clarke and E. Balka, eds. 2015. Boundary Objects and Beyond: Working with Susan Leigh Star. Cambridge, MA: MIT Press.

Chubin, D. E. W. Chu. 1989. Science off the Pedestal: Social Perspectives on Science and Technology. Belmont, CA: Wadsworth Pubs.

Clarke, A. E. 1984. "Subtle Sterilization Abuse: A Reproductive Rights Perspective." In Test Tube Women: What Future for Motherhood?, edited by R. Arditti, R. D. Klein and S. Minden, 188212. Boston: Pora/Routledge and Kegan Paul. Reprinted in second edition, 1989.

Clarke, A. E. 1995. "Modernity, Postmodernity and Human Reproductive Processes c1890-1990, or 'Mommy, Where do Cyborgs Come From Anyway?'" In The Cyborg Handbook, edited by C. H. Gray with H. J. Figueroa-Sarriera S. Mentor, 139-156. New York: Routledge. 
Clarke, A. E. 1998. Disciplining Reproduction: Modernity, American Life Sciences and the Problems of Sex. Berkeley: University of California Press.

Clarke, A. E. 2008. "Introduction: Gender and Reproductive Technologies in East Asia." EASTS: East Asian Science and Technology Studies: An International Journal 3 (1): 303-326.

Clarke, A. E. 2010. "In Memoriam: Susan Leigh Star (1954-2010)." Science, Technology and Human Values 35(5): 581-600.

Clarke, A. E. 2012. "Turning Points and Trajectories in a Late-Blooming Career." In Studies in Symbolic Interaction, Vol. 38. Blue-Ribbon Papers: Behind the Professional Mask: The Autobiographies of Leading Symbolic Interactionists, edited by N. Denzin, 75-102. DOI: 10.1108/S0163-2396(2012)0000038002

Clarke, A. E. 2015. "Anticipation Work: Abduction, Simplification, Hope." In Boundary Objects and Beyond: Working with Susan Leigh Star, edited by G. Bowker, S. Timmermans, A. E. Clarke and E. Balka, 85-119. Cambridge, MA: MIT Press.

Clarke, A. E. and K. Charmaz, eds. 2014. Grounded Theory and Situational Analysis. Sage Benchmarks in Social Research Series, 4 volumes. London: Sage.

Clarke, A. E. I. Fletcher. In preparation. "Interview with Adele Clarke." In Talking STS: Reflections on the Making of a Field, 1966-2016, edited by Fadhila Mazerani and Pablo Schyfter.

Clarke, A.E., C. Friese and R. Washburn, eds. 2015. Situational Analysis in Practice: Mapping Research with Grounded Theory. Walnut Creek, CA: Left Coast Press.

Clarke, A. E. S. L. Star. 2007. “Social Worlds/ Arenas as a Theory-Methods Package." In Handbook of Science and Technology Studies, edited by E. Hackett, O. Amsterdamska, M. Lynch and J. Wacjman, 113-137. Cambridge, MA: MIT Press, $3^{\text {sedition. }}$

Clarke, A. E. and A. Wolfson. 1984. "Class, Race and Reproductive Rights." Socialist Review 78:110-120. Reprinted in Women, Class and the Feminist Imagination: A Socialist-Feminist Reader, edited by K. V. Hansen and I. J. Philipson, 258-267. Philadelphia: Temple University Press.

Clarke, A. E., J. Shim, L. Mamo, J. Fosket, and J. Fishman, eds. 2010. Biomedicalization: Technoscience and Transformations of Health and Illness in the US. Durham, NC: Duke University Press.

Cozzens, S. and T. Gieryn, eds. 1990. Theories of Science in Society. Bloomington, IN: Indiana University Press.

Edge, D. [1998] 1999. “Three Thoughts from the Coal Face." In History of Science and Technology in Education and Training in Europe, edited by C. Debru, 249-251. Luxembourg: Office for Official Publications of the European Communities.

Fee, E. 1983. "Women and Health Care: A Comparison of Theories." In Women and Health: The Politics of Sex in Medicine, edited by E. Fee, 17-34. Farmingdale, NY: Baywood.

Fu, D. 2007. “How Far Can East Asian STS Go?" EASTS: East Asian Science, Technology and Society: An International Journal 1:1-14.

Gad, C. D. Ribes. 2014. "The Conceptual and Empirical in Science Technology Studies." Science, Technology and Human Values 39 (2): 183-191. 
Gossel, P. P. 1999. "Packaging the Pill." In Manifesting Medicine: Bodies and Machines v. I, edited by R. Bud, 105-122. Amsterdam: Overseas Publishers Association.

Greeley, K. and S. Tafler. 1980. "History of Science for the People: A Ten Year Perspective." In Science and Liberation, edited by R. Arditti, P. Brennan and S. Cavrak, 369-388. Boston: South End Press.

Gray, C. H., H. J. Figueroa-Sarriera and S. Mentor, eds. 1995. The Cyborg Handbook. New York: Routledge.

Hansen, K. V. and I. J. Philipson, eds. 1990. Women, Class and the Feminist Imagination: A SocialistFeminist Reader. Philadelphia: Temple University Press.

Haraway, D. 1985. "A Manifesto for Cyborgs: Science, Technology, and Socialist Feminism in the Last Quarter." Socialist Review 80: 65-107. Reprinted in Women, Class and the Feminist Imagination: A Socialist-Feminist Reader, edited by K. V. Hansen and I. J. Philipson, 580618. Philadelphia: Temple University Press.

Hess, D. J. 2009. "The Potentials and Limitations of Civil Society Research: Getting Undone Science Done." Sociological Inquiry 79 (3): 306-327.

Hilgartner, S. 1997. “The Sokal Affair in Context." Science Technology and Human Values 22(4): 506522.

Kuhn, T. [1962] 1966. The Structure of Scientific Revolutions. Chicago: University of Chicago Press, 3 Edition.

Latour, B. and S. Woolgar. 1979. Laboratory Life: The Social Construction of Scientific Facts. Beverly Hills: Sage.

Lin, W.-H. J. Law. 2015. “We Have Never Been Late-comers! Making Knowledge Spaces for East Asian and Technosocial Practices I." EASTS: East Asian Science, Technology and Society: An International Journal 9 (2): 117-126.

MacKenzie, D. 1978. "Statistical Theory and Social Interests: A Case Study." Social Studies of Science 8 (1): 35-83.

MacKenzie, D. 1982. “Technology as Capitalist Restructuring." Review of Science, Technology, and the Labour Process by L. Levidow and A. Young. Radical Science Journal 12:141-145.

Mazerani, F. and P. Schyfter, eds. In preparation. Talking STS: Reflections on the Making of a Field, 1966-2016.

Mills, C.W. 1959. The Sociological Imagination. New York: Oxford University Press.

Murphy, M. 2012. Seizing the Means of Reproduction: Entanglements of Feminism, Health, and Technoscience. Durham, NC: Duke University Press.

Ny, A., ed. 1988. Science, Hegemony and Violence: A Requiem for Modernity. New Delhi, India: Oxford University Press.

Nelson, A. 2013. Body and Soul: The Black Panther Party and the Fight against Medical Discrimination. Minneapolis: University of Minnesota Press.

Quet, M. and M. Noel. 2014. "From Politics to Academics: Political Activism and the Emergence of Science and Technology Studies in South Korea." East Asian Science, Technology and Society 8 (2): 175-193.

Ravetz, J. R. 1971. Scientific Knowledge and its Social Problems. Oxford: Clarenden Press. 
Ruzek, S. B. 1978. The Women's Health Movement: Feminist Alternatives to Medical Control. New York: Praeger.

Star, S. L. 1979. "Sex Differences and Brain Asymmetry: Problems, Methods and Politics in the Study of Consciousness." In Genes and Gender II: Pitfalls in Research on Sex and Gender, edited by R. Hubbard and M. Lowe, 113-130. New York: Gordian Press.

Star, S. L. 1989. Regions of the Mind: Brain Research and the Quest for Scientific Certainty. Stanford, CA: Stanford University Press.

Star, S. L. 1995. "Introduction." In Ecologies of Knowledge: Work and Politics in Science and Technology, edited by S. L. Star, 13-46. Albany: State University of New York Press. Reprinted in Boundary Objects and Beyond: Working with Susan Leigh Star, edited by G. Bowker, S. Timmermans, A. E. Clarke and E. Balka, 47-68. Cambridge, MA: MIT Press, 2016.

Sweeney, E. M. 2015. "Shifting Paradigms on the Verge of a Revolution: The Evolution of the ASA Section on Science, Knowledge, and Technology." SKATOLOGY: Newsletter of the Science, Knowledge, and Technology Section of the ASA. Spring Edition: 4-9.

Werskey, G. 1978. The Visible College: The Collective Biography of British Scientific Socialists of the 1930s. New York: Holt, Reinhart and Winston.

Werskey, G. 2007. “The Marxist Critique of Capitalist Science: A History in Three Movements?" Science as Culture, 16(4): 397-461.

Woolgar, S. and J. Lezaun. 2013. "The Wrong Bin Bag: A Turn to Ontology in Science and Technology Studies?" Social Studies of Science 43(3): 321-340.

Zilsel, Edgar. [1942] 2000. "The Sociological Roots of Science." Social Studies of Science 30 (6): 935949.

Zuckerman, H. 1989. "The Sociology of Science." In Handbook of Sociology, edited by N. Smelser, 511-574. Newbury Park, CA: Sage. 